\title{
Impact of Supply Chain Flexibility and Supplier Development on Supply Chain Effectiveness in Automotive Industry of Pakistan
}

\author{
Kafeel Uddin Quershi ${ }^{1 *}$, Danish Ahmed Siddiqui ${ }^{2}$ \\ ${ }^{1}$ Research Scholar, Karachi University Business School, University of Karachi, PAKISTAN \\ ${ }^{2}$ Associate Professor, Karachi University Business School, University of Karachi, PAKISTAN \\ *Corresponding Contact: \\ Email: kaif0332@gmail.com
}

Manuscript Received: 01 Jan 2019 - Revised: 25 Feb 2019 - Accepted: 15 March 2019

\begin{abstract}
The purpose of this research is to study the significance of supply chain strategies namely supplier development and supply chain flexibility towards supply chain effectiveness in automotive industry of Pakistan. A survey was conducted using self-administered questionnaires to collect data from 300 supply chain professionals working in automotive manufacturing companies of Pakistan. The finding indicates that supplier development and supply chain flexibility have positive and significant impact on supply chain effectiveness in automotive industry of Pakistan. The research will help policy makers and management to integrate strategies and practices related to supplier development and flexibility to improve supply chain effectiveness in order to be competitive in automotive industry of Pakistan.
\end{abstract}

Keywords: supplier development, supply chain flexibility, supply chain effectiveness

This article is is licensed under a Creative Commons Attribution-NonCommercial 4.0 International License.

Attribution-NonCommercial (CC BY-NC) license lets others remix, tweak, and build upon work non-commercially, and

although the new works must also acknowledge \& be non-commercial.

\section{INTRODUCTION}

Universally, it has been accepted the automotive industry is a significant contributor to the global economy and a major driver of growth of a nation's economy. The automotive industry has been described as 'both a form and function' based product involving high level of engineering as well as being positioned as a fashion product. The industry since it uses outputs of nearly all manufacturing industries, supports upstream (mining, steel etc.) and a downstream industry (finance, insurance, after -market etc.) has rightly been called as "the industry of industries". Global automotive companies have lowest EBIT margins in comparison to industry leaders $(10.4 \%)$ but having the highest number of inventory turns (18.2) and best in class delivery performance $(97.3 \%)$. The industry is asset, material and labor intensive which calls for involved operational planning and execution at all levels of management. 
The changing business conditions from globalization, economic uncertainty to new technologies and increasing consumer demands of the 21st century has led to companies facing several issues. The supply chains in the automobile industry become increasingly complex, as manufacturers design and build vehicles globally. The challenges that often stand in the way such as long order-to-delivery lead times, unreliable production schedules, excess inventory across the supply chain, lengthy demand planning cycles and lack of visibility of suppliers which affect profitability and higher shareholder value. The effect of the global economic meltdown increased the pressure on automotive executives to make right decisions about their supply chain for better performance.

Pakistan Automotive industry account for $4 \%$ of Pakistan GDP and is one of the fastest growing industry of the country. The sector plays a pivotal role in economic growth and currently as a whole providing employment to 3.5 million people. Therefore automotive is consider as important sector in Pakistan economy, but unfortunately recent development regarding trade liberalization, China Pakistan Economic Corridor, increasing customer demands and competition are the significant challenges this industry is facing. In order to be competitive locally and globally the automotive manufacturers are concern about improving productivity and performance. In order to achieve these aims, it is necessary to improving firm performance through supply chain effectiveness. Supply chain is a popular tool in a highly challenging and competitive environment such as today, where an efficient and effective supply chain strategy is necessary for improving the organizational competitiveness, is a must for automotive manufacturers and their component manufacturers so as to meet changing consumer demands (Weiss \& Ambe, 2010).

Supply chain in automotive industry is most complex as each vehicle contains approximately more than 20,000 parts derives from thousands of different local and global suppliers, which contributing towards increasingly tough and a more vulnerable environment in supply chain. Supply chain vulnerability is defined as a phenomenon responsible for increasing risks in supply chain; these risk can be direct or indirect however the origin of indirect risk is out of their visibility horizon and unforeseen therefore companies are often incapable of handling indirect supply chain risks (Kersten et al., 2006). Global sourcing, lean management and high dependence on supplier and customers are those factors which formulate supply chain vulnerability. Supply chain effectiveness is significantly impact by supply chain vulnerabilities which occur because of fundamentals in both upstream and downstream operations in a value chain (Chopra, 2004). According to Wagner (2009), suggest that not every improvement strategy is effective in reducing supply chain vulnerability. Supply chain effectiveness is a multidimensional concept which generally include supplier partnership, inventory management and technological advancement (Sundram, 2011). According to Juttner (2003) and Chopra (2004), visibility, flexibility, supplier assessment and inventory control are essential in risk mitigation and increasing firm performance.

In many industries supply chain performance and effectiveness has become a critical source of competitive advantage. Whereas supply chain performance and effectiveness are mostly interchangeable used in many studies. Automotive industry has the most vulnerable business environment and to reduce vulnerability severe effects, several strategies must be embedded within supply chain development. Therefore, further studies on the impacts of supply chain strategies on supply chain effectiveness are needed. In 
addition, to the best of our knowledge, the effectiveness of supply chain and the suggested mitigation strategies in enhancing the supply chain effectiveness in automotive industry has not yet been empirically investigated. Hence this study examines the impact of supplier development and supply chain flexibility on supply chain effectiveness in automotive companies of Pakistan.

\section{LITERATURE REVIEW}

Supplier development is the way toward working with specific vendor on a balanced premise to enhance their execution and capacities for the advantage of the purchasing association. The results from an empirical study suggest that the relationship between the goal to improve a supplier's capabilities and knowledge transfer from the buyer to the supplier firm is moderated by the degree of human interaction. Buying firms pursuing the strategy to improve supplier capabilities rely more intensively on training and co-location of buyer and supplier employees to leverage the knowledge transfer to the supplier firm (Wagner, 2009) and (Krause, 1997).

The article of Noraizah (2016) said that advanced technologies which include eprocurement can assist facilitate effective answers for procuring organizations you acquire from suppliers based on five rights so e-procurement also can make supplier improvement extra at ease from the wrong pick out or alert approximately the suppliers issue.

A research of Raymond (2017) investigate the mediating position of 3 crucial relational abilities- absorptive capacity (AC), transitive memory structures (TMS), and organizational interoperability (OI); on the flexibility of buyer-provider relationships and overall performance in retail supply chains. The authors examined 4 hypotheses at the mediating role of relational talents on supply chain flexibility and retail performance, controlling for size, period of courting, and marketplace segment. Results confirmed that the 3 relational capabilities partly mediated the high-quality impact of CF and PCF on operational overall performance in huge center and niche stores.

Supplier development is any attempt to enhance the provider's overall performance and skills to fulfill the enterprise's contemporary and future wishes (Prahinski, 2004). Krause (1997) define dealer development as any effort of the buying firm to enhance the performance and/or the abilities in their suppliers with the cause to attain the fast and lengthy-term targets of the shopping for company.

Modi (2007) affords a conceptual model of an agency's efforts to improve supplier overall performance. Then latent variable structural equation modeling (LVSEM) is used to check the model with records for 215 provider improvement reports from US manufacturing companies. The effects propose that evaluation and certification efforts are the maximum essential supplier improvement conditions before mission operational expertise transfer sports consisting of website visits and provider schooling. Furthermore, collaborative inter-organizational communication is recognized as critical supporting issue in remodeling an enterprise's efforts to broaden suppliers into dealer overall performance upgrades.

During provider development, the customer quite regularly sends out a go-functional development group to teach the provider and offer it with expertise approximately ways in which it is able to improve (Asare, 2013). Through focusing on dealer development, 
agency are able to generate many jointly beneficial opportunities consisting of expanding the competitive panorama (pricing, service level) between the organization's present and capability companies.

Quick changes inside the enterprise surroundings have put manufacturing companies below pressure to improve excellent, shipping and responsiveness even as simultaneously decreasing costs (Kannan and Tan, 2006). Supplier improvement permits corporations to better make use of their resources, boom the value brought and allows manufacturing corporations to be extra powerful in responding changing needs. Modi (2007) and Wagner (2009) finish that the development of a supplier capabilities calls for extra than low involvement activities which includes audits or incentives as well.

Afzal and Abbas (2011) conducted a qualitative study on examining e-sourcing in automotive industry of Pakistan. It was identify that e-source which is form of supplier management benefited automotive industry of Pakistan in number of ways e.g. cost reduction, delivery time reduction, faster information processing, deployment of total quality principles in supplier selection, enhanced collaboration and integration within (internal) and across (external) supply chain networks.

According to Imam et al. (2015) research, in which qualitative technique was used to study supplier management to explore in depth knowledge about the concern using structured interviews. It is identified that supplier management can be effective in growing automotive industry of Pakistan.

Supply chain risk management analyzes network structure, supply chain complexity and operational dynamics to understand its effect on organization and to provide thorough understanding to the supply chain members (Hallikas, 2004). Risk management needs to be integrated into an organization's culture to provide legal path for risk management activities in an organization (Christopher and Peck, 2004).

Organization resources are scarce, in order to reduce reliance and uncertainty outsourcing activities are strategic response to this conditions (Hatonen and Eriksson, 2009). According to the study by (Oke, 2009), based on the analysis on supply chain vulnerability specific strategies are require in handling low-likelihood and can have high-impact on risks reduction. According to (Norman, 2004), suggest that tactical strategies for daily operational accidents should be distinguished from those for uncertainties of a catastrophic nature based on probability and severity of the risk consequences. A strategy is an iterative process that evaluates the cost-benefit trade-off analysis of supply chain operation. An empirical research undertaken by Ibrahim (2010) revealed that three dimensions of supply chain process integration were statistically significant to firm performance. Furthermore, information flow integration shows a greater influence than physical and financial flow integration. The framework adapted from the previous studies attention on firm overall performance impacts of digitally enabled deliver chain integration (SCI) talents. The research framework turned into pre-examined the use of multivariate analysis In addition, the findings can also invite possibilities for comparative research especially with different industries in addition to other developing and advanced economies.

According to Sanchez and Perez (2005) research which focuses exploring relationship between supply chain flexibility dimension and firm performance in automotive industry, 
it is identified that there is a positive relationship between supply chain flexibility and firm performance. The research further describe that flexibility as upstream flexibility and downstream at shop floor level. Finally, the results indicate that flexibility capabilities are enhanced in supply chains with higher environmental uncertainty, technological complexity, and mutual understanding, but with lower interdependence among the agents involved in the supply chain.

The published reviews consider different aspects of flexibility such as definitions, classification and measurement of flexibility, choices, interpretation and requests for flexibility. Referring to the several papers which have proposed useful taxonomies, different aspects of flexibility can be outlined, such as functional aspects (flexibility in operations, marketing, logistics), hierarchical aspects (flexibility at shop, plant or company level), measurement aspects (focused on global flexibility measures vs. context specific ones), strategic aspects (centred on the strategic relevance of flexibility), time horizon aspects (long-term vs. short-term flexibility), and object of change (flexibility of product, mix, volume).

The basic flexibility types comprise flexibility of the system components. The main components of a manufacturing system are its machines, the material handling units and the transporting network. The system flexibility types are composites of the basic flexibility types at the manufacturing system level. An important type of system flexibility with implications for the supply chain system is routing flexibility. Finally, the aggregate flexibility types represent the aggregated attributes of the manufacturing system technology enabling it to cope with the variety of changes and needs at the strategic level. Zhang (2003) divided dimensions of flexibility into those defined internally - defined as flexible competencies - and those perceived by the customer - defined as flexible capabilities.

Zhang (2003) were able to demonstrate empirically that internal dimensions of flexibility (like machine or labor are translated into flexible capacities (volume and mix), which in turn have a significant positive impact on customer satisfaction. Their results suggested that firms that considered flexibility both from an internal and external viewpoint were more likely to specify the flexible competencies required to achieve the flexible capabilities required for customer satisfaction. Jordan and Graves (1995) also demonstrated that flexibility initiatives carried out over a chain of plants (external flexibility) substantially outperform flexibility initiatives carried out within a single plant (internal flexibility). Similarly, Olhager and West (2002) have recognized supply chain flexibility needs to integrate internal and external flexibility dimensions, its analysis may be more appropriate to study the influence on firm performance

A first research issue concerns the relationship between supply chain flexibility and firm performance. Flexibility- the ability to adapt to change - is critical to the long-run survival of an organization (Upton, 1994). In the short run, flexibility affects the competitive posture of the firm and may impact its overall profitability. In this case, many sources of uncertainty have to be handled (Giannoccaro, 2003). Flexibility allows switching production among different plants and suppliers, so that management can cope with internal external variability (Chen et al., 1994). Emphasis on various dimensions of supply chain flexibility may be directly linked to overall firm performance. 
Supply chain flexibility is the ability to adapt to changes in the global competitive environment in a fast and cost-effective manner. Supply chain flexibility is a strategic initiative that enables the firm to respond rapidly to changes in the market, including unanticipated actual disruptions in the supply chain (Swafforf, 1987). Supply chain flexibility is widely seen as a strategic response to increasingly uncertainty and competition (Merschamnn, 2010). There are two types of supply chain flexibility which is micro flexibility and macro flexibility. Micro flexibility is means how fast a supply chain could detect and respond to issues and opportunities in the short term. Macro flexibility is the speed at which a company's supply chain adapts strategies or market place changes.

In addition, the challenge of supply chain flexibility first is changing market conditions which are customer expectation for speed and low costs have reached new highs in our always-on, digital and global world. Supply chain flexibility has been touted as a key strategy for managing and mitigating the risks associated with uncertainties in supply chain. However, the ability to manage these risks for seamless day-to-day operations in retail stores depends entirely on how flexibility strategies are deployed (Raymond, 2017).

\section{Research Methodology}

\section{Research Questions}

How supplier development and supply chain flexibility could affect supply chain effectiveness in automotive industry of Pakistan?

\section{Framework}

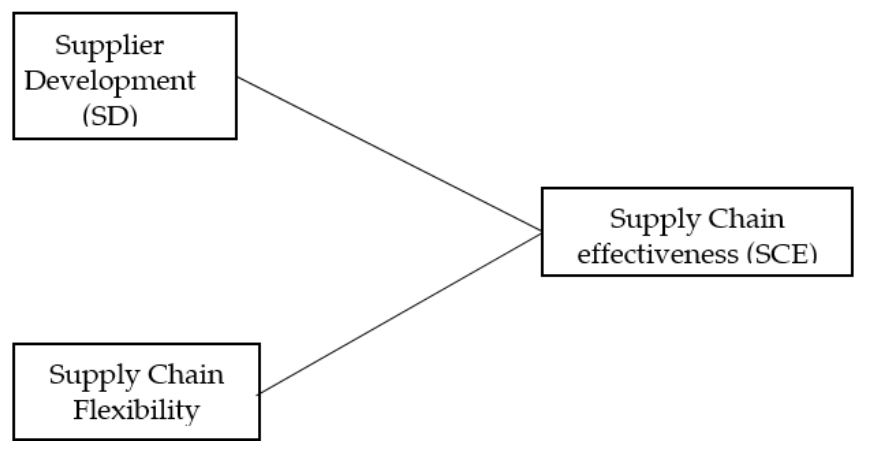

\section{Hypotheses}

$\mathrm{H}_{\mathrm{a} 1}$ : There is a significant relationship between supplier development and supply chain effectiveness in automotive industry of Pakistan

$\mathrm{H}_{\mathrm{a} 2}$ : There is a significant relationship between Supply chain flexibility and supply chain effectiveness in automotive industry of Pakistan

$\mathrm{H}_{\mathrm{a} 3}$ : There is a significant impact of supplier development and supply chain flexibility on supply chain effectiveness in automotive industry of Pakistan.

\section{Research Design}

The reliable and suitable approach for identifying relationship between different variables is quantitative approach thus the nature of this research is Quantitative. The research aims 
to find answer to real business issue using the data and theory by statically analyzing data, which make this research casual which is about finding the relationship between supply chain effectiveness, supply chain flexibility and supplier development.

\section{Sampling Design}

The targeted population for this study is the supply chain professional currently working in automotive industry of Pakistan. A Sample drawn from the overall population in a research is a subset of whole (Saunders et al., 2009). Sample size of this research is 300 which is approximately $15 \%$ of total population; due to the issue of credibility, convenience and also that our population is unknown so no statistical technique or formulae can be used for the determination of the sample size (Saunders et al., 2009).

Convenience sampling is adopted in this study, which is a non-probability sampling technique. The reason behind this sampling technique selection in this study is because the population is unknown and it is unable to find exact no of supply chain professionals working in automotive industry due to non-regularity and data availability.

\section{Procedure of Data Collection}

The data is collected using adopted questionnaire with the consent of respondents without any persuade. This data collection technique is very useful in a situation where closed ended questions need to be asked in order to get precise and to the point data from the primary sources. The questionnaire was distributed among supply chain professionals working in automotive industry with in Pakistan. Both physical and electronic mean of communication like internet and self-administrator survey was conducted based on the convenience of researcher.

\section{Descriptive Analysis}

It is exploratory data analysis which offers researcher a method to analyze particular information. It explains the fundamental characteristics and feel of the data to get the quick review of data analysis. It involves mean, median and standard deviation however simple descriptive statistics is used in present research is demographic analysis which provide the respondent profile analysis and insights.

\section{Reliability and Factor Analysis}

Reliability is related to consistency of the scores obtained when same scale is used at different. The reliable scale yield same scores when data is collected from different sample and time frame. The consistency of the items in an instrument is measured through reliability.

Exploratory factor analysis based on principal component analysis has employed to identify factors from different items of each construct i-e Independent and dependent variables under study. Factors loading have also been identified in order to check that how each item loads into its consequent factor.

\section{Correlation Analysis}

The correlation analysis measures the relationship between two variables. The coefficient of correlation tells us the strength of relationship between two variables, it value can take any value between \pm 0.01 to \pm 1.00 . A relationship can be of two nature; positive and 
negative. Positive coefficient shows a positive relationship that as increase in values of one variable increases the value of other variable. By contract a negative coefficient represent a negative relationship, as increase in value of one variable decreases the value of other variable (Saunders et al., 2009).

Table 1: Pearson's $r$ indices of correlation

\begin{tabular}{cc}
\hline Pearson's $r$ & Indication \\
\hline Between \pm 0.80 to \pm 1.00 & High correlation \\
Between \pm 0.60 to \pm 0.79 & Moderately high correlation \\
Between \pm 0.40 to \pm 0.59 & Moderate correlation \\
Between \pm 0.20 to \pm 0.39 & Low correlation \\
Between \pm 0.01 to \pm 0.19 & Negligible correlation \\
\hline
\end{tabular}

Source :(Hair, Wolfinbarger, Ortinau, \& Bush, 2008)

\section{Multiple Regression Analysis}

Multiple Regression analysis is used to predict dependent variable value through several independent variables. It also explained the change in dependent variable can be occurring due to independent variables. The co-efficient of determination $\left(R^{2}\right)$ shows the degree of prediction which your regression equation can find. The co-efficient of determination can take any value between \pm 0.01 to \pm 1.00 (Saunders et al., 2009).

\section{RESULT AND Discussion}

In this chapter the data analysis and findings are discussed. The data collected through questionnaire from 300 respondents. Out of 300, 200 questionnaires were taken out as usable and were used for data analysis in this research. The first step before testing the hypothesis is to examine the demographic characteristics of data and the reliability analysis of the tool and the items used. In the second step to test the three hypothesis correlation and regression analysis approach is used using SPSS software.

Table 2: Demographic Factors

\begin{tabular}{|c|c|c|c|}
\hline Profile & Categories & No & $\%$ \\
\hline \multirow{4}{*}{ Experience } & Less than 1 year & 23 & $12 \%$ \\
\cline { 2 - 4 } & $1-3$ years & 23 & $12 \%$ \\
\cline { 2 - 4 } & $4-6$ years & 45 & $23 \%$ \\
\cline { 2 - 4 } & $7-9$ years & 64 & $32 \%$ \\
\cline { 2 - 4 } & $10-12$ years & 36 & $18 \%$ \\
\cline { 2 - 4 } & $13-15$ years & 9 & $5 \%$ \\
\cline { 2 - 4 } Designation & 16 years or more & 0 & $0 \%$ \\
\hline \multirow{4}{*}{ Education } & Executive/Officer & 23 & $12 \%$ \\
\cline { 2 - 4 } & Assistant Manager & 65 & $33 \%$ \\
\cline { 2 - 4 } & Manager & 98 & $49 \%$ \\
\cline { 2 - 4 } & Head of Department & 14 & $7 \%$ \\
\hline & Graduation & 40 & $20 \%$ \\
\cline { 2 - 4 } & Master & 146 & $73 \%$ \\
\cline { 2 - 4 } & M.Phil & 10 & $5 \%$ \\
\cline { 2 - 4 } & Phd & 4 & $2 \%$ \\
\hline
\end{tabular}


Table 2 present details related to the demographic factors. The demographic factors include experience, designation and education. From the table above, it observed that the manager contributed more in participating in this survey as compared to other designations. Among the total respondents who participated in this survey, $73 \%$ holds master's degree which indicates the high level of literacy of the participants. It is shown that most of the respondents have 7-9 years of experience in the field. Further details of the demographic distributions are explained in the table.

The Table 3 of reliability analysis illustrate the items and Cronbach's alpha value of each independent and dependent variables in this research. The result indicates that Cronbach's Alpha values of all variables items range from are more than 0.5 which mean that all are significant and reliable for further process.

Table 3: Reliability statistics

\begin{tabular}{|c|c|c|}
\hline Variables & No. of items & Cronbach's alpha \\
\hline Supplier development & 7 & .832 \\
\hline Supply chain flexibility & 6 & .864 \\
\hline Supply chain effectiveness & 6 & .827 \\
\hline
\end{tabular}

Table 4 presents factor loading, that how each item loads into its relative principal component. Factor loading value of each item into its relative principal component should be greater than 0.40 . There are 7 components for supplier development, supply chain flexibility consists of 6 items and Supply Chain effectiveness is consist of 6 items. Factor loading values range from 0.441 to 0.820 . All cross loading values were ignored because of the value less than 0.40 . Overall, results of factor analysis satisfy the criteria of construct validity.

Table 4: Factor Analysis

\begin{tabular}{|c|c|c|c|}
\hline \multicolumn{4}{|l|}{ Rotated Component Matrix ${ }^{a}$} \\
\hline Items & 1 & 2 & 3 \\
\hline Used multiple suppliers for the purchased item to create competitive & .670 & & \\
\hline Site visits to the supplier to help them improve performance. & .625 & & \\
\hline Conducted training and education programs supplier personnel. & .671 & & \\
\hline Consideration to enhance business relationships in the future. & .627 & & \\
\hline $\begin{array}{l}\text { Assessed the supplier's performance through a formal supplier } \\
\text { evaluation system. }\end{array}$ & .717 & & \\
\hline $\begin{array}{l}\text { Development of targeted quality and other improvement benchmarks } \\
\text { within the supplier. }\end{array}$ & .739 & & \\
\hline We involve key suppliers in the product design and development stage. & .705 & & \\
\hline $\begin{array}{l}\text { It is possible to switch the purchase of items from one supplier to } \\
\text { another. }\end{array}$ & & .528 & \\
\hline It is possible to change the quantity of supplier's order. & & 685 & \\
\hline $\begin{array}{l}\text { Different modes of transportation are available in delivering products to } \\
\text { the customers. }\end{array}$ & & .852 & \\
\hline Production capacity is sufficient to accommodate an increase in demand. & & .715 & \\
\hline $\begin{array}{l}\text { Overtime or temporary worker is possible to cope with short term } \\
\text { demand fluctuation }\end{array}$ & & .852 & \\
\hline $\begin{array}{l}\text { Most suppliers are capable of producing a small quantity due to } \\
\text { relatively low setup costs. }\end{array}$ & & .715 & \\
\hline
\end{tabular}




\begin{tabular}{|l|r|l|}
\hline Transportation cost of supply chain operation in this company is. & .441 \\
\hline Warehouse cost of supply chain operation in this company is. & & .749 \\
\hline Inventory cost of supply chain operation in this company is. & & .733 \\
\hline Logistics administration cost of supply chain operation in this company is. & & .828 \\
\hline Product cost in this company & & .548 \\
\hline Order Delivered in the right quantity, specification without damage & & .828 \\
\hline $\begin{array}{l}\text { Extraction Method: Principal Component Analysis. } \\
\text { Rotation Method: Varimax with Kaiser Normalization. }\end{array}$ \\
\hline
\end{tabular}

\section{Correlation and Regression Analysis}

In line with the research question and hypothesis which aims to examine how supplier development, supply chain flexibility affect supply chain effectiveness in automotive industry, the correlation analysis approach is employed.

Table 5 illustrates the result of test. Based on the table it can be seen that there is a moderate correlation or substantial relationship between supplier development and supply chain effectiveness. The relationship is significant with $p$ value equal to 0.000 at 0.05 confidence interval level (2-tail). This result supports $\mathrm{H}_{\mathrm{a}}$ : There is a significant relationship between supplier development and supply chain effectiveness in automotive industry. The result also indicates that supplier development and supply chain effectiveness have positive relationship which means increasing supply chain development will increase supply chain effectiveness. Supplier development is related to improving supplier performance using several measures, this include e-procurement, supplier training and development, strategic contracts and just-in-time purchase management. Supplier development enables firms to better utilize their resources, increase the value added and allows manufacturing firms to be more effective in responding changing needs (Modi, 2007). According to Tarli (2016) supplier development and supply chain effectiveness have statistically significant positive relationship. This positive relationship with supply chain effectiveness yield greater and improve organization performance.

Table 5: substantial relationship between supplier development and supply chain effectiveness

\begin{tabular}{|c|c|c|c|c|}
\hline \multicolumn{5}{|c|}{ Pearson Correlations } \\
\hline & & SD & SCF & SCE \\
\hline \multirow{3}{*}{ SCE } & Coefficient & $.422^{* *}$ & $.488^{* *}$ & 1 \\
\hline & Sig. (2-tailed) & .000 & .000 & .000 \\
\hline & $\mathrm{N}$ & 200 & 200 & 200 \\
\hline
\end{tabular}

** Correlation is significant at 0.05 level (2 tailed); $\mathrm{SD}=$ Supplier Development; $\mathrm{SCF}=$ Supply chain flexibility; SCE $=$ Supply chain effectiveness

From the Table 5 it can also be seen that there is a moderate correlation between supply chain flexibility and supply chain effectiveness. The relationship is significant with $\mathrm{p}$ value equal to 0.000 at 0.05 confidence interval level (2-tail). This result supports $\mathrm{H}_{\mathrm{a} 2}$ : There is a significant relationship between supply chain flexibility and supply chain effectiveness in automotive industry. Supply chain flexibility is related to ability to change when market condition changes with minimal effort, time and cost. Supply chain flexibility can be measured by two most agreed upon dimensions, range and response. Range is variety of alternatives available and response is the level of easiness with which adaption can be 
carried out (Sanchez and Perez, 2005). A company should have different modes of transportation options, can switch purchase from one supplier to another, have possibility to change order quantity from supplier and the production capacity with labor in case of rapid change in demand.

Table 6: Degree of goodness fit

\begin{tabular}{|c|c|c|c|c|c|}
\hline \multicolumn{7}{|c|}{ Model Summary } \\
\hline Model & R & R Square & Adjusted R Square & F & Sig. \\
\hline 1 & $.539^{\mathrm{a}}$ & .291 & .283 & 40.338 & $.000 \mathrm{~b}$ \\
\hline \multicolumn{2}{|l|}{ a. Predictors: (Constant), SCF, SD } \\
\hline
\end{tabular}

Table 6 illustrates the result of model summary section which shows the degree of goodness fit of regression model. The $R$ value is (0.539), which indicate that there is a moderate correlation among supplier development, supply chain flexibility and supply chain effectiveness. Thevalue of $\mathrm{R}^{2}$ is (0.291) which states that only $29.1 \%$ of variation in dependent variable which is supply chain effectiveness can be explained by all two independent variable in this regression model. It is also observe that Significance F value is less than 0.000 which states that combined effect of all independent variable is significant.

Table 7: Estimated coefficients and significance level

\begin{tabular}{|c|c|c|c|c|c|c|}
\hline \multicolumn{7}{|c|}{ Coefficients $^{\mathrm{a}}$} \\
\hline \multirow{2}{*}{\multicolumn{2}{|c|}{ Model }} & \multicolumn{2}{|c|}{$\begin{array}{l}\text { Unstandardized } \\
\text { Coefficients }\end{array}$} & \multirow{2}{*}{$\begin{array}{c}\text { Standardized } \\
\text { Coefficients } \\
\text { Beta }\end{array}$} & \multirow[t]{2}{*}{$\mathrm{T}$} & \multirow[t]{2}{*}{ Sig. } \\
\hline & & $\mathrm{B}$ & Std. Error & & & \\
\hline \multirow[t]{3}{*}{1} & (Constant) & .536 & 283 & & 1.893 & .060 \\
\hline & SD & .305 & .080 & .255 & 3.812 & .000 \\
\hline & SCF & .384 & .069 & .375 & 5.595 & .000 \\
\hline
\end{tabular}

The results in Table 7 show the details of the estimated coefficients and significance level of all the independent variables. For supply chain flexibility and supplier development variable it shows that the coefficient value (0.384) and (0.305) respectively. So for every unit increase in supply chain flexibility and supplier development a unit increases in supply chain effectiveness. In conjunction to this if we analyze the significance values $p=0.000$ and $p=0.000$ of supplier development and supply chain flexibility respectively, the result yield that there is a significant and positive impact of supplier development and supply chain flexibility on supply chain effectiveness. The findings of the current research is consistent with the research of (Tarli, 2016), the study finds that all supply chain strategies, namely, supply chain flexibility and supplier development have a positive relationship and impact on the supply chain effectiveness in manufacturing concerns. According to the results obtained, regression equation is as follows:

$\mathrm{SCE}=0.536+0.305(\mathrm{SD})+0.384(\mathrm{SCF})+\mathrm{e}$

Here 0.538 is the value of constant, 0.305 and 0.384 are elasticizes of supplier development and supply chain flexibility respectively. SCE refers to supply chain effectiveness that is our dependent variable, whereas e is error term. 


\section{CONCLUSION}

Pakistan Automotive industry is one of the fastest growing sectors of the country. The sector plays a pivotal role in economic growth. However unfortunately recent development regarding trade liberalization, China Pakistan Economic Corridor, increasing customer demands and competition are the significant challenges this industry is facing. Supply chain in automotive industry is most complex different local and global suppliers, which contributing towards increasingly tough and a more vulnerable environment in supply chain. To promote effectiveness in supply chain of an automotive manufacturing organization the management may undertake effective supply chain strategies. The primary purpose of this research is to examine supply chain strategies and their impact on supply chain effectiveness, this provide theoretical or empirical guidance of how supply chain strategies can be used effectively and boost their impact on supply chain.

This study fills the potential gap in the literature by undertaking research on these two supply chain strategies (supplier development and supply chain flexibility). These strategies have impacted in achieving supply chain effectiveness. Thus, in a situation of decision making theoretical perspective of potential deployment of supply chain strategies will be available as a means to achieve supply chain effectiveness.

From research implementation and significant viewpoint, this research will support in supply chain strategy deployment decision, deciding which supply chain strategy should be used through detailed consideration of all strategies. Managing culture of relationship among supplier and supply chain partners is vital for managers to boost their confidence before forming or deploying a supply chain strategy. The study has great importance as it benefits supply chain managers, especially for those who are aiming to establish supplier development and supply chain flexibility. It is necessary for managers to understand the importance of relationship of these factors in supply chains.

\section{FUtURE RECOMMENDATION AND LIMITATION}

This research is much specific in terms of finding the supply chain effectiveness strategies effect of only manufacturing automotive companies in Pakistan but in future researcher may conduct research for finding supply chain effectiveness strategies affect specific to overall manufacturing or any other sector companies.

In addition, this research present strong support that supply chain effectiveness in automotive industry can be to some extent determine by supplier development and supply chain flexibility which means that current research is limited to the certain variables only, so in future, for the sake of further improvement in the current research, many other unexplored variables should be study to study supply chain effectiveness in Pakistan.

Further, the scope of current research is limited to Karachi only so there exists an opportunity for future researchers to widen the scope by extending the research to other cities or maybe throughout the nation for a more exact measure of variables.

This research is conducted in a country where the supply chain management is just in his emerging phase. The reason behind this is lack of advancement, regulation and management culture. Many companies have been facing difficulty because they do not have functionality of supply chain; they still work in culture approach. 


\section{REFERENCES}

Afzal \& Abbas (2011). Impact of E-Source Application on Key Business Strategies - Evidences from Automotive Industry of Pakistan. Journal of Quality and Technology Management , 7 (2), 37-62.

Asare, A. K. (2013). The relationship between supplier developement and firm performance: The mediating role of marketing process improvement. Journal of Business $\mathcal{E}$ Industrial Marketing , 28 (6), 523-232.

Chen et al. (1994). "Production planning models for a central factory with multiple satellite factories. International Journal of Production Research , 32 (6), 1431-50.

Chopra (2004). Managing risk to avoid supply chain breakdown. Sloan Management Review , pp. 5361.

Christopher, M and Peck, H. (2004). Building the resilient supply chain. International Journal of Logistics Management , 15 (2).

David M. Cutler, J. M. (2013). What moves stock prices. The journal of Portfolio management , No 1 (23), 208-215.

Giannoccaro (2003). "Uncertainty in supply chain inventory management: a fuzzy approach. European Journal of Operational Research , 149, 185-96.

Hallikas (2004). Risk management process in supplier network. International Journal of Production Economics , 90 (1), 47-58.

Hasan, M. (2017). Supply Chain Management in Readymade Garments Industry, Bangladesh. Asian Business Review, 7(3), Art. \#14, pp. 103-110. https://doi.org/10.18034/abr.v7i3.18

Hatonen and Eriksson (2009). 30+ years of research and practice of outsourcing- Exploring the past and anticipating the future. Journal of International Management , 15 (2), 142-155.

Ibrahim, Z. (2010). SCM Practices and Firm Performance: An Empirical Study of the Electronics Industry in Malaysia. International Journal of Technology Diffusion , 37 (4), 48-55.

Imam, Raza and Husain. (2015). Effective Supplier Management in Automobile Industry in Pakistan. Journal of Applied Environmental and Biological Sciences , 5 (12), 167-177.

Jordan and Graves. (1995). Principles on the benefits of manufacturing process flexibility. Management Science , 41 (4), 577-94.

Juttner, U. P. (2003). Supply chain risk management: outlining an agenda for future research. International Journal of Logistic: Research and Applications , 6 (4), 197-210.

Kannan and Tan (2006). The impact of supplier selection and buyer-supplier engagement on relationship and firm performance. International Journal of Physical Distribution and Logistic Management , 67 (4), 755-775.

Kersten, Hohrath \& Böger (2006). In an empirical approach to supply chain risk management: development of a strategic framework in managing risk in supply chain: how to build reliable collaboration in logistic. Hamburg University of Technology , 1-20.

Khan, A., \& Siddiqui, D. A. (2018). Information Sharing and Strategic Supplier Partnership in Supply Chain Management: A Study on Pharmaceutical Companies of Pakistan. Asian Business Review, 8(3), Art. \#16, pp. 115-122. https://doi.org/10.18034/abr.v8i3.162

Krause (1997). Critical elements of supplier development: Buying firm perspective. Europe Journal of Purchasing \& Supply Chain Management , 3 (1), 21-31.

Merschamnn (2010). Supply chain flexibility, uncertainty and firm performance: An empirical analysis of German Manufacturing Firms. International Journal of Production Economics , 45-53.

Modi (2007). Supplier development: Improving supplier performance through knowledge transfer. Journal of Operations Management , 25 (1), 42-64. 
Nadeem, K., \& Siddiqui, D. A. (2017). The Effect of Strategic Orientation on Green Supply Chain Practices and Performance: A Case of Manufacturing Companies in Pakistan. Asian Business Review, 7(2), Art. \#8, pp. 59-70. https://doi.org/10.18034/abr.v7i2.12

Noraizah (2016). Abridgment of Traditional Procurement and E-Procurement: Definitions, Tools and Benefits. ournal of Emerging Economies and Islamic Research, , 34 (9), 1-18.

Norrman, A., \& Lindroth, R. (2004). Categorization of supply chain risk and risk management. In C. Brindley (Ed.), Supply chain risk (pp. 14-27).

Oke (2009). Managing distruptions in supply chains: A case study of a retail supply chain. International Journal of Production Economics , 118 (1), 168-174.

Olhager and West (2002). The house of flexibility: Using the QFD approach to deploy manufacturing flexibility. International Journal of Operations \& Production Management , 22 (1), 50-79.

Othman (2016). The Relationship between Supply Chain Integration, Just-In-Time and Logistics Performance: A Supplier's Perspective on the Automotive Industry in Malaysia. Journal of Supply chain Management , 5 (1), 44-51.

Prahinski (2004). Supplier evaluations: communication strategies to improve supplier performance. Journal of Operations Management, , 22 (1), 39-62.

Raymond (2017). Improving retail supply flexibility using buyer-supplier relational capabilities. International Journal of Operations \& Production Management , 37 (3), 343-363.

Sanchez and Perez (2005). Supply chain flexibility and firm performance. Journal of Operations $\mathcal{E}$ Production Management , 25 (7), 681-700.

Saunders, M., Lewis, P., \& Thornhill, A. (2009). Research Methods for Business Students. Prentice Hall, $5^{\text {th }}$ Edition

Sharma, S. (2011). Determinants of Equity Share Prices in India. Journal of Arts, Science \& Commerce , II (4), 51-60.

Sundram (2011). Supply chain management practices in the electronics industry in Malaysia: Consequences for supply chain performance. An International Journal , 18 (6), 834-855.

Swafforf (1987). Manufacturing strategy, environmental uncertainty and performance: a path analytic model", Management Science. California Management Review , 33 (1), 509-24.

Tarli (2016). The effects of supply chain visibility, supply chain flexibility, supplier development and inventory control toward supply chain effectiveness. An International Journal , 29 (3), 804-812.

Titus, S., Mburu, T., Koror, J., \& Muathe, S. (2012). Environmental Factors that influence Supply Chain Management Implementation in the Manufacturing Industries in Kenya: A Case of Manufacturing Industries in Nairobi, Kenya. ABC Journal of Advanced Research, 1(2), 104-111.

Upton (1994). The management of manufacturing flexibility. California Management Review , 36 (1), $72-$ 89.

Wagner (2009). Supplier development: communication approaches activities and goals. International Journal of Production Research , 47 (12), 3161-3177.

Weiss \& Ambe (2010). Strategic supply chain framework for the automotive industry. African Journal of Business Management , 4 (10), 2110-2120.

Zhang (2003). Manufacturing flexibility: defining and analyzing relationships among competence, capability and customer satisfaction. Journal of Operations Management , 21 (2), 173-91. 